ISSN 1991- 8690

Website: http://jsci.utq.edu.iq
الترقيم الدولي 8690 - 2591

Email: utjsci@utq.edu.iq

\title{
Diagnostic study of Toxoplasma gondii in students of Thi-Qar university-Iraq by Real- Time PCR
}

\author{
Rabab Ali Al-Mosawi* \\ Bassad A. Al-Aboody ${ }^{* *}$ \\ Manal B. Al-Temimi** \\ AL_Naser Preparatory School. Directorate Education of Thi Qar/ Iraq \\ *** Dept. of Biology. College of Science. Thi Qar University/Iraq \\ ** Dept. of Biology_College of Science. Thi Qar University/ Iraq \\ E-mail: basadpar70@yahoo.com
}

Tel:07801520949

\section{Abstract}

Toxoplasma gondii is a unique intracellular parasite, which infect a large proportion of the world, population, but clinically un commonly causes significant disease. The present study was performed for the first time in Thi-Qar province to estimate the prevalence of toxoplasmosis among university students . Venous blood samples were collected from 319 (111 males and 208 females) apparently healthy students ,they have ages between (18-42) years attended from different colleges of Thi-Qar university-Iraq, during the period from October 2013 to April 2014. Enzyme linked Immunosorbant Assay (ELISA), was used to evaluate the presence of anti-Toxoplasma IgM and IgG antibodies and detection of $B 1$ gene of T.gondii DNA by Real-Time Polymerase Chain Reaction(RT-PCR). The results indicated that $70(21.94 \%)$ of students were exposed positive for anti-Toxoplasma antibodies,17 (5.33\%) of them had IgM,38 $(11.91 \%)$ had $\mathrm{IgG}$, and $15(4.70 \%)$ had both IgM and IgG. Statistically, significant difference between them. The results showed significant difference between males and females in rate of positive for anti- Toxoplasma antibodies, which recorded 24 (7.52\%) and $46(14.42 \%)$ respectively . Besides the serological diagnosis of T.gondii Real-Time PCR (RT-PCR) technique was used to confirm the infection with T.gondii by detection B1 gene of T.gondii DNA in the blood of students. out of 319 students only $6.26 \%$ showed positive toxoplasmosis among those $8(2.50 \%)$ were males and $12(3.76 \%)$ were females. The positive result in RT-PCR analysis were distributed on the patterns of the antiToxoplasma antibodies by ELISA test, it was no found any positive blood samples with IgM,IgG and both IgM and IgG respectively whereas 20 positive cases of no anti-Toxoplasma antibodies. Real-Time PCR test in blood of students has advantages in detection of recent or active toxoplasmosis.

Keywords: Toxoplasma gondii, Real-Time PCR, B1 gene, University students

$$
\begin{aligned}
& \text { دراسة تثخيصية لطفيلي المقوسة الكونديه Toxoplasma gondii في طلبة جامعة ذي قار -العرلق باستخدام تفاعل } \\
& \text { سلسلة البلمرة ذو الوقت الحقيقي }
\end{aligned}
$$

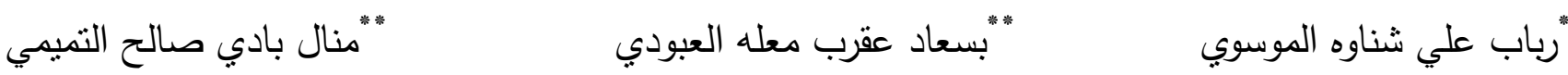

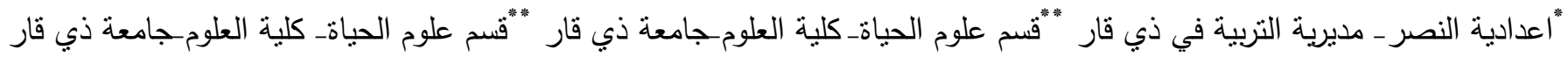

$$
\begin{aligned}
& \text { الخلاصه } \\
& \text { المقوسه الكونديه هو طفيلي يعيش داخل الخلايا حيث انه يصيب عدد كبير من سكان العالم لكن ليس من الثائع ان يسبب امراض خطيرة.الدراسه }
\end{aligned}
$$

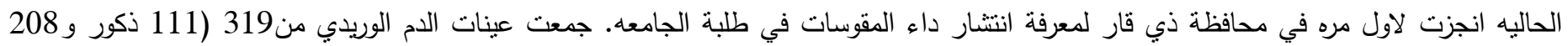

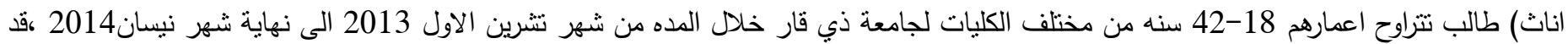




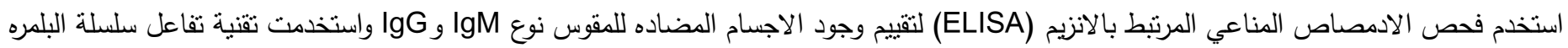
ذو الوقت الحقيقي للكثف عن الجين B1 في الحامض النووي DNA لطفيلي المقوسة الكوندية .اظهرت النتائج 70من الطلبه يحملون الاجسام المضاده

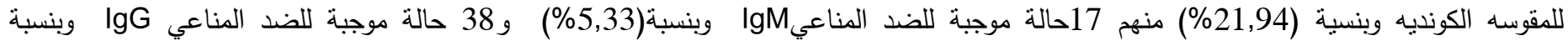

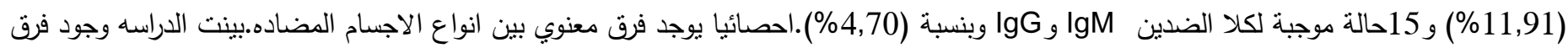
معنوي بين الذكور والاناث في المعدل الكلي لكن لايوجد فرق معنوي بينهما من حيث انواع الاجسام المضاده حيث سجلت24 حالة موجبة من الذكور وبنسبة (467,52\% حالة موجبة من الاناث وبنسبة (14,42\%) يحملون الاجسام المضاده للطفيلي استخدمت الدراسة بالاضافة الى التشخيص السيرولوجي للمقوسه الكوندية تقنية تفاعل سلسلة البلمره ذو الوقت الحقيقي للكثف عن جين B1 في الحامض النووي DNA لطفيلي المقوسة الكوندية في دم الطلبة . اجري الفحص على319 عينة دم كانت هناك 20 حالة موجبة فقط لداء المقوسات وبنسبة 6,26\% بينهم 2,5\% ذكور و 3,76\% اناث.النتائج الموجبه التي شخصت بواسطة تقنية Real-Time PCR قد وزعت حسب انواع الاجسام المضادة فلم تسجل الدراسة اي حالة موجبة مع IgM و و و و

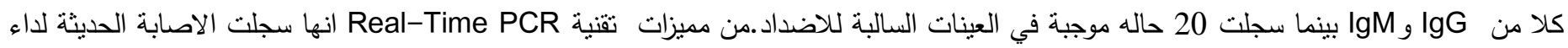
المقوسات في دم الطلبة. الكلمات المفتاحية : طفيلي المقوسات الكوندية ، تفاعل سلسلة البلمرة ذو الوقت الحقيقي ،الجين b1، طلبة الجامعة .

\section{Introduction}

Toxoplasmosis is caused by an obligate intracellular tissue protozoan parasite Toxoplasma gondii, which is able to infect humans as well as other warm blooded domestic and wild animals. The infection has a world-wide distribution with approximately onethird of the world population estimated to be exposed to this parasite (Dubey and Jones, 2008). Toxoplasmosis is a widespread zoonotic disease caused by T.gondii. It has economic relevance to both veterinary and human medicine (Hill et al .,2005).In sheep and goats infection not only results in significant reproductive looses ,but also has implication for public health since consumption of infected meat and milk can facilitate zoonotic transmission (Bisson et al.,2000). T. gondii has a wide variety of hosts, as almost all warm blooded animals can be infected. Sexual replication of the parasite occurs only in domestic cats and wild felidae (definite hosts), while asexual replication occurs in both intermediate and final hosts (Frenkel, 1970; Tenter et $a l ., 2000)$. Oocysts are passed in the feces of cats and become infectious within 21 days of being shed .Tachyzoites survive and multiply only in an intra cellular location while tissue cysts containing few or many bradyzoites occur in the tissues of infected animals within a week of infection(Lainson, 1958) Ingestion of tissue cysts in infected meat or oocysts from soil, food, or water contaminated with cat feces are the two major routes of transmission(Montoya and Remington, 2008).Rarely, transmission of T.gondii occur through blood transfusions and organ transplantations (Singh,2003).In immunocompetent individuals, $90 \%$ of $\mathrm{T}$. gondii infections are asymptomatic (Kravetz and Fedeman, 2005).Symptomatic infections usually cause low grade fever, malaise, headache and cervical Lymphadenopathy. Severe manifestations such as encephalitis, myocarditis, hepatitis and pneumonia are rare but can complicate acute toxoplasmosis (Kravetz and Fedeman., 2002) and may even lead to death in immunocompromised patients(Singh ,2003). The diagnosis of T.gondii infection may be established by serologic tests, molecular methods, histological demonstration of the parasite, a toxoplasmin skin test and by isolation of the organism (Remington et al .,2001). Molecular methods rely on PCR for the specific detection or analysis of T. gondii DNA. These methods have proved to be simple, sensitive, reproducible and cost-effective, and have been applied to a variety of clinical samples from animals and humans (Contini et al.,2005; Bastien et al.,2007).Real-time PCR has been used to amplify and quantify DNA from the $T$. gondii B1 gene (Costa et al.,2000). Real-time PCR utilizes the 59 nuclease activity of Taq DNA polymerase (Holland et al., 1991) to cleave a non extendible, fluorescencelabeled hybridization probe during the extension phase of PCR.The fluorescence of the intact probe is quenched by a second fluorescent dye, usually 6carboxy-tetramethyl- rhodamine (TAMRA). This study, we describe the development of a real-time quantitative PCR for the detection of $\mathrm{T}$. gondii. The use of this methodology will facilitate the diagnosis of $\mathrm{T}$. gondii in clinical laboratories. 


\section{Material and Methods \\ Serological test}

The sera of all cases were tested for the presence of specific IgM and IgG anti-Toxoplasma antibodies via ELISA kits (BioChik Diagnostics Company, USA) according to the manufacture'sinstructions

\section{Isolation of genomic DNA from whole blood}

DNA was extracted from the whole blood samples of the study groups using acommercial purification system (Reagent Genomic DNA extraction kit (.Invitrogen. USA))following the manufacture's instruction for DNA purification from blood. Purified DNAmolecules were stored at $-80 \circ \mathrm{C}$, after estimation of DNA concentrationand purity, The extracted genomic DNA from whole blood samples was checked by using Nanodrop spectrophotometer (THERMO.USA), that check and measurement the purity of DNA through reading the absorbance in at $(260 / 280 \mathrm{~nm})$.

\section{Real-Time PCR}

Real-Time PCR basedTaqMan probe was performed for rapid detection of $\mathrm{T}$. gondii according to method described by Meihuilin et al. (Fernanda et al.,2010). Real-Time PCR TaqMan probe and primers were used for amplification of conserved region B1 gene in $\mathrm{T}$. gondii . These primers were provided by (Bioneer Company. Korea) as showed in table (1).

Table (1): Real-Time PCR TaqMan probe and primers

\begin{tabular}{|c|c|c|c|}
\hline Primer & \multicolumn{2}{|c|}{ Sequence } & Product size \\
\hline \multirow{2}{*}{ Bl primer } & $\mathrm{F}$ & TCCCCTCTGCTGGCGAAAAGT & \multirow{2}{*}{ 94bp } \\
\cline { 2 - 3 } & $\mathrm{R}$ & AGCGTTCGTGGTCAACTATCGATTG & \\
\hline Bl probe & \multicolumn{3}{|c|}{ 5-6FAMI-TCTGTGCAACTTTGGTGTATTCGCAG -TAMRA-3 } \\
\hline \hline
\end{tabular}

The Real-Time PCR amplification reaction was done by using (AccuPower ${ }^{\circledR}$ DualStarTM qPCR PreMixBioneer. Korea) and the qPCR master mix were prepared for each sample according to company instruction as following table (2):

Table (2): The qPCR master mix

\begin{tabular}{|c|c|}
\hline RT-PCR master mix & Volume \\
& \\
\hline DNA template & $5 \mu \mathrm{L}$ \\
\hline Forward B1 gene primer (20pmol) & $2.5 \mu \mathrm{L}$ \\
\hline Reverse B1 gene primer (20pmol) & $2,5 \mu \mathrm{L}$ \\
\hline TaqMan B1 gene probe (20pmol) & $2.5 \mu \mathrm{L}$ \\
\hline DEPC water & $37.5 \mu \mathrm{L}$ \\
\hline Total & $50 \mu \mathrm{L}$ \\
\hline
\end{tabular}

These qPCR master mix reaction components that mentioned in table above were added into AccuPower ${ }^{\circledR}$ DualStarTM qPCR PreMixtubes which containing Taq DNA polymerases, dNTPs, 10X buffer for TaqMan probe amplification. Then tubes placed Exispin vortex centrifuge at $3000 \mathrm{rpm}$ for 3 minutes, after that transferred into MiniOpticon Real-Time PCR system and applied the following thermocycler conditions as the following table (3):

Table (3): Thermocycler conditions

\begin{tabular}{|c|c|c|}
\hline Step & Condition & Cycle \\
\hline Pre-Denaturation & $95^{\circ} \mathrm{C} \mathrm{5} \mathrm{min}$ & 1 \\
\hline Denaturation & $95^{\circ} \mathrm{C} \mathrm{20} \mathrm{sec}$ & \multirow{2}{*}{45} \\
\hline Annealing/Extension & $60^{\circ} \mathrm{C} \mathrm{30} \mathrm{sec}$ & \\
\cline { 1 - 1 } Detection (Scan) & & \\
\hline
\end{tabular}

\section{Statistical analysis}

Data were analyzed with chi-square and $\mathrm{P}$ value < 0.05 was considered statistically significant.

\section{Results}

The present study carried out on 319 apparently healthy students from Thi-Qar university that included in this study, 111 male students and 208 female students ,to elucidate Toxoplasma gondii infection by using Enzyme Linked Immunosorbent Assay (ELISA), as well as Real Time Polymerase Chain Reaction(Real timePCR). Results presented in this study showed that overall the prevalence of toxoplasmosis were 70(21.94\%) among those 24(7.52.\%) were males and 46(14.42\%) were females by using ELISA test while the overall prevalence of toxoplasmosis were $20(6.26 \%)$ among those $8(2.50 \%)$ were males and $12(3.76 \%)$ were females by using Real time quantitative PCR, as shown in table(4).

Table (4) percentage distribution of students from Thi-Qar university infected with toxoplasmosis according to test type

\begin{tabular}{|c|c|c|c|c|c|c|c|c|c|}
\hline \multirow[t]{3}{*}{ Test type } & \multicolumn{3}{|c|}{ Males } & \multicolumn{3}{|c|}{ Females } & \multicolumn{3}{|r|}{ Total } \\
\hline & \multirow[b]{2}{*}{ No. } & \multicolumn{2}{|r|}{ tve } & \multirow[b]{2}{*}{ No. } & \multicolumn{2}{|r|}{ tve } & \multirow[b]{2}{*}{ No. } & \multicolumn{2}{|r|}{ tve } \\
\hline & & No. & $\%$ & & $\mathrm{No}$ & $\%$ & & No. & 0 \\
\hline EllSA test & 111 & 24 & 7,52 & 208 & 46 & 14.42 & 319 & 70 & 21. \\
\hline Real-timePCR & 111 & 8 & 2.5 & 208 & 12 & 3.76 & 319 & 20 & 6.26 \\
\hline
\end{tabular}




\section{ELISA IgM and IgG tests for toxoplasmosis seroprevalence}

The current study tried to estimate the actual percentage of toxoplasmosis in students from different colleges by using specific tests ELISA IgM and IgG. Out of 319 students 17(5.33\%) were had acute toxoplasmosis characterized by the presence of positive IgM antibodies,38(11.91\%) of samples had chronic toxoplasmosis characterized by the presence of positive IgG antibodies only, while $15(4.70 \%)$ of samples had both acute and chronic toxoplasmosis characterized by the presence positive of both $\operatorname{IgM}$ and IgG antibodies .The statistical analysis showed significant differences between them $(\mathrm{p}<0.05)$, table $(5)$.

Table (5) percentage distribution of students from Thi-Qar university infected with toxoplasmosis according to ELISA $\operatorname{IgM}$ and $\operatorname{IgG}$ tests

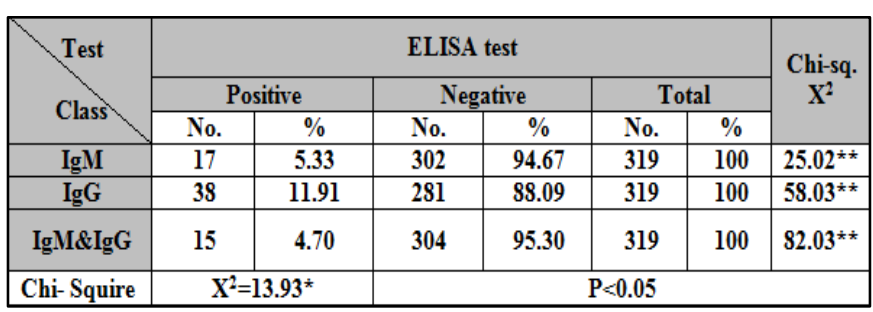

\section{Detection of T.gondii gene by B1 gene Real- Time quantitative PCR}

Besides the serological diagnosis of T.gondii Real-Time PCR (RT-PCR) technique was used to confirm the infection with T.gondii by detection of T.gondii DNA in the blood of students .Toxoplasma gondii DNA was successfully extracted and analyzed by RT-PCR. The study revealed that out of 319 students only $20(6.26 \%)$ showed positive toxoplasmosis by RTPCR technique among those $8(2.50 \%)$ were male and $12(3.76 \%)$ were female. Statistically, no significant difference between them $(\mathrm{p}<0.05)$. A typical amplification plot (change in fluorescent signal versus cycle numbers) with a CT of :28-37 was obtained .The cycle threshold value (CT), indicative of the quantity of target gene at which the fluorescence exceed a preset threshold was determined, where the negative samples show as undetermined by amplification plot as shown in figure (1).

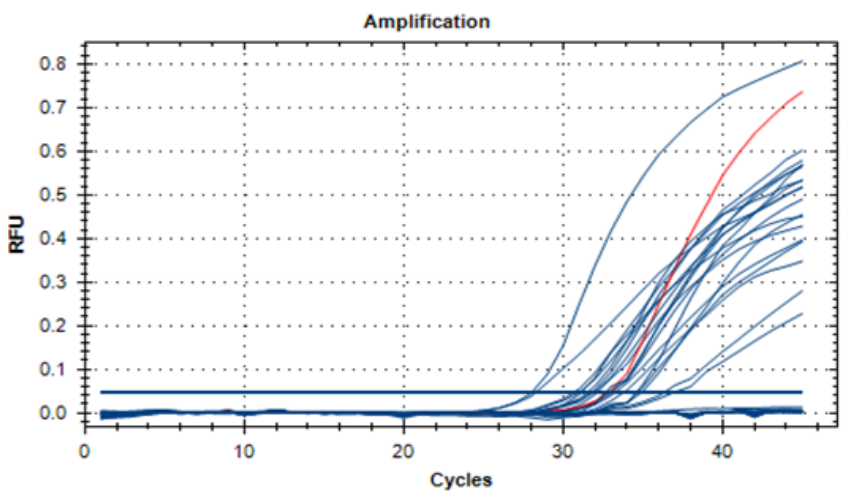

Figure (1): Real-Time amplification plot of $B 1$ gene in T.gondii from blood samples of students .Where, Blue plots: 20 positive samples, Red plot: Positive control

(DNA Toxoplasma gondii)

\section{Correlation between real time PCR analysis and ELISA results}

Students 20(6.26) who recorded positive results in RT-PCR analysis were distributed on the patterns of the anti-Toxoplasma antibodies by ELISA test, it was no found any positive blood samples with IgM,IgG and both $\operatorname{IgM}$ and $\operatorname{IgG}$ respectively whereas 20 positive cases of no anti-Toxoplasma antibodies . as shown in table (6), figure (2).

Table (6) Correlation between real time PCR analysis and ELISA results

\begin{tabular}{|c|c|c|c|c|c|c||}
\hline $\begin{array}{c}\text { Real-time } \\
\text {-PGR } \\
\text { ELISA-test }\end{array}$ & \multicolumn{2}{|c|}{$\begin{array}{c}\text { Real-time PCR } \\
+\mathrm{ve}\end{array}$} & \multicolumn{2}{c|}{$\begin{array}{c}\text { Real-time PCR } \\
\text {-ve }\end{array}$} & \multicolumn{2}{c|}{ Total } \\
\cline { 2 - 7 } & No. & $\%$ & No. & $\%$ & No. & $\%$ \\
\hline ELISA +ve & 0 & 0 & 70 & 21.94 & 70 & 21.94 \\
\hline ELISA-ve & 20 & 6.27 & 229 & 71.79 & 249 & 78.06 \\
\hline Total & 20 & 6.27 & 299 & 93.73 & 319 & 100 \\
\hline
\end{tabular}

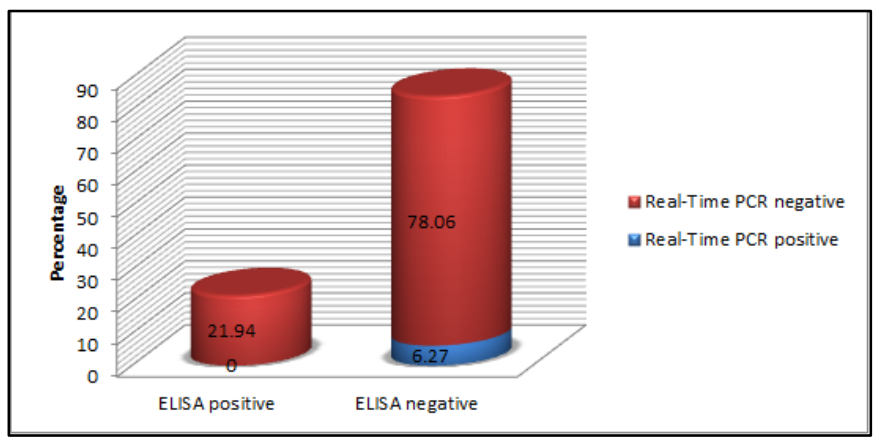

Figure (2) Correlation between real time PCR analysis and ELISA result 


\section{Discussion}

Besides the serological diagnosis of T.gondii RealTime PCR (RT-PCR) technique was used to confirm the infection with T.gondii by detection $B 1$ gene of T.gondii DNA in the blood of students. Toxoplasma gondii DNA was successfully extracted and analyzed by RT-PCR. The diagnostic value of PCR for the detection of T.gondii in blood samples has been evaluated from both immunecompetent and immunecompromised patients (Ho-Yen et al., 1992; Bou et al., 1999; Kompalic-Cristo et al., 2007).Several PCR-based techniques have been developed as alternative diagnostic measurements for T.gondii infection. These techniques make use of the most conserved gene sequences among different strains of T.gondii (Ellis, 1998), including the Blgene repetitive sequence, theP30 (SAG1) gene and ribosomal DNA. The use of the $B 1$ gene for T.gondii detection originated with Burg et al.(1989).The B1 gene, although of unknown function ,is mostly exploited in a variety of diagnosis and epidemiological studies thanks to its specificity and sensitivity (Ivovic et al .,2o12; Tlamcan et al.,2013). The cycle threshold value $\left(\mathrm{C}_{\mathrm{T}}\right)$ for positive samples in Real-Time PCR ranged from $\mathrm{C}_{\mathrm{T}} 28$ to $\mathrm{C}_{\mathrm{T}} 37$. The $\mathrm{C}_{\mathrm{T}}$ of a reaction is determined mainly by the amount of template present at the start of the amplification reaction.If a large amount of template is present at the start of the reaction, relatively few amplification cycles will be required to accumulate enough product to give a fluorescent signal above background.Thus, the reaction will have a low, or early, $\mathrm{C}_{\mathrm{T}}$. In contrast, if a small amount of template is present at the start of the reaction, more amplification cycles will be required for the fluorescent signal to rise above background. Thus, the reaction will have a high, or late, $\mathrm{C}_{\mathrm{T}}$. This relationship forms the basis for the quantitative aspect of real-time PCR (Carr and Moore, 2012). The study revealed that out of 319 students only $6.26 \%$ showed positive toxoplasmosis among those $8(2.50 \%)$ were male and $12(3.76 \%)$ were female. Statistically, no significant difference between them $(\mathrm{p}<0.05)$.The positive result was higher in this study than those recorded by Gunel et al.(2012) in Turkey, who demonstrated that rate was $(1.3 \%)$ and with Chiang et al.(2012) in Taiwan, who recorded no active parasitemia was detected by real-time PCR assay, while rate was lower in this study than those recorded by Wallon et al.(2010), who recorded that the rate infection of toxoplasmosis was $(69 \%$,) other studies in Iraq( AlAbudy,2014; Abbas et al.,2014 and Al-nasrawi et al.,2014) who showed that rate was $(38.0 \%, 17,7 \%, 16 \%)$ of aborted women .The explanation of these differences stated by other researcher may be resulted to the use of only healthy students for both sexes in this study gave findings that may therefore differ from findings in other population. Students 20(6.26) who recorded positive results in RT-PCR analysis were distributed on the patterns of the anti-Toxoplasma antibodies, it was no found any positive case with $\operatorname{IgM}, \operatorname{IgG}$ and both $\operatorname{IgM}$ and $\mathrm{IgG}$ respectively whereas 20 positive cases of no anti -Toxoplasma antibodies. This result was in- line with the result obtained by Chiang et al.(2012) who showed that out of 1783 blood from healthy blood donors were tested for the presence of T.gondii antibodies and DNA using ELISA and RT-PCR respectively ,5(0.28\%) 166(9.3\%),tested positive for anti-Toxoplasma $\operatorname{IgM}$ and $\operatorname{IgG}$ respectively .No active parasitemia of positive ELISA result was detected by real-time PCR assay and other study by Pignanelli.(2011) who revealed that no active parasitemia of anti- Toxoplasma IgG was detected by real-time PCR assay. Also, these results was agreed with a number studies has already shown that a positive PCR result is not always accompanied by positive serology indicating local synthesis of antibodies (Talabani et al.,2009,Al-nasrawi et al.,2014). Current diagnosis of toxoplasmosis dependent on serological detection it may fail to detect specific antiToxoplasma IgG or IgM during the active phase of T. gondii infection, because these antibodies may not be produced until after several weeks of parasitemia. Therefore, in this study we used highly specific molecular as Real-Time PCR based TaqMan probe and primers to amplify the $\mathrm{T}$. gondii $\mathrm{B} 1$ gene for detection of Toxoplasma gondii ( Lin et al.,2000).

\section{Conclusion}

We have developed a rapid, sensitive, and quantitative real-time PCR for detection of T.gondii. The advantages of this technique for the diagnosis of toxoplasmosis in a clinical laboratory are discussed.

\section{$\underline{\text { Reference }}$}

Abbas,H.H.; Al-Asadiy,Y.D. and AlTememi,M.B.(2014). Detection Toxoplasma gondii by Rreal-timePCR in abotive and Pregnant women in Al-Muthanna province. JIARM. V.2(1). P 310-316.

Al-Abudy, R.K.(2014).Diagnostic and Epidemiological study of Toxoplasma gondii and Rubella virus in aborted women by technology Real-Time PCR in Thi-Qar province-Iraq. M.S.c. Thesis College of 
Education of pure science .University of Thi-Qar.P 167

Al-nasrawi, H.AA.; Naser, H.H. and Kleaf,S.F(2014) Molecular detection of Toxoplasma gondii in human and chicken by Real-Time PCR technique ISSN. V2( 3) 1023-1027

Bastien, P.; Jumas-Bilak, E.; Varlet-Marie, E. and Marty, P. (2007). Three years of multi-laboratory external quality control for the molecular detection of Toxoplasma gondii in amniotic fluid in France. Clin. Microbiol. and Infect. 13, 430-433

Bisson, A.; Maley, S.; Rubaire-Akiiki, CM; Watling, J.M. ( 2000). The seroprevalence of antibodies to Toxoplasma gondii in domestic goats in Uganda. Acta Tropica, 76: 33-38.

Bou ,G.;Figueroa, MS.; MartÌ-Belda, P.; Navas, E. and Guerrero, A. (1999) . Value of PCR for detection of Toxoplasma gondii in aqueous humor and blood samples from immunocompetent patients with ocular toxoplasmosis. J Clin Microbiol; 37: 34658.

Burg, J. L.; Grover, C. M.; Pouletty, P. and Boothroyd, J. C. (1989). Direct and sensitive detection of a pathogenic protozoan, Toxoplasma gondii, by polymerase chain-reaction. J. Clin. Microbiol., 27(8):1787-1792.

Carr, A.C. and Moore, S.D.(2012)."Robust Quantification of Polymerase Chain Reactions Using Global Fitting". In Lucia, Alejandro. PLoS ONE.,7(5): e37640

Chiang, T-Y.; Hsieh, H-H.; Kuo, M-C.; Chiu, K-T.;Lin, W-C.;Fan,C-K;Fang,C-T and Ji,D-D. (2012) .Seroepidemiology of Toxoplasma gondii Infection among Healthy Blood Donors in Taiwan. PLoS ONE 7(10): e48139. doi: 10.1371/ journal. pone. 0048139.P 1-6.

Contini, C., Seraceni, S., Cultrera, R., Incorvaia, C., Sebastiani, A. and Picot, S. (2005). Evaluation of a Real-time PCR-based assay using the light cycler system for detection of Toxoplasma gondii bradyzoite genes in blood specimens from patients with toxoplasmicretinochoroiditis. Int. J. for Parasitol. 35, 275-283

Costa, J.M.; Pautas, C.; Ernault, P.; Foulet, F., Cordonnier, C. and Bretagne, S. (2000). Real-time PCR for diagnosis and follow-up of Toxoplasma reactivation after allogeneic stem cell transplantation using fluorescence resonance energy transfer hybridization probes. J. Clin. Microbiol., 38, 2929-2932

Dubey J.P.and Jones J.L.(2008). Toxoplasma gondii infection in humans and animals in the United States. Int J Parasitol, 38:1257-1278.

Ellis, J. T. (1998). Polymerase chain reaction approaches for the detection of Neospora caninum and Toxoplasma gondii. Int. J. Parasitol. 28:10531060

Fernanda. S. G.; Sandra, M. N.; Hilda, F. P.; Solange, M. G. (2010). Toxoplasma gondii: diagnosis of experimentaland natural infection in pigeons (Columba livia) by serological, biological and moleculartechniques.Rev. Bras. Parasitol. Vet., Jaboticabal, (19), p. 238-243.

Frenkel,J.K.(1970)Pursuing Toxoplasma .J infect Dis 122,553-559.

Gunel, T.; Kalelioglu, I.; Ermis, H.; Has, R. and Aydinli, K. (2012). Large Scale pre-diagnosis of Toxoplasma gondii DNA Genotyping By RealTime PCR on Amniotic Fluid. Article., 26 (2):2913-2915.

Hill D.E., Chirukandoth S. and Dubey J.P. (2005). Biology and epidemiology of Toxoplasma gondii in man and animals.J. Anim. Health Res. Rev., 6: 41-61.

Holland, P. M., R. D. Abramson, R. Watson, and D. H. Gelfand. (1991). Detection of specific polymerase chain reaction product by utilizing the 59-39 exonuclease activity of Thermus aquaticus DNA polymerase. Proc. Natl. Acad. Sci. USA 88:72767280.

Ho-Yen, DO.; Joss, AW.; Balfour,AH.; Smyth, ET.; Baird, D. and Chatterton, JM. (1992). Use of the polymerase chain reaction to detect Toxoplasma gondii in human blood samples. J Clin Pathol; 45: 910-3

Ivovic, V.; Vujanic, M.; Zivkovic, T.; Klun, I. and Djurkovic-Djakovic, O.( 2012) Molecular Detection and Genotyping of Toxoplasma gondii from clinical samples, Toxoplasmosis-Recent Advances, Dr. Olgica Djurković Djaković, Eds., ISBN: 978-953-51- 0746-0:103-120.

Kravetz, J. D. and Federman, D. G. (2002 ).Catassociated zoonoses. Archives J. of Int. Med.; 162: 1945-1952. 
Kravetz, J. D. and Federman, D. G. (2005) .Toxoplasmosis in pregnancy. American Journal of Medicine; 118: 212-216.

Kompalic-Cristo, A.;Frotta ,C.; Suárez-Mutis, M.; Fernandes, O.and Britto, C.( 2007). Evaluation of a real-time PCR assay based on the repetitive B1 gene for the detection of Toxoplasma gondii in human peripheral blood. Parasitol Res; 101: 61925 .

Lainson, R.( 1958). Observations on the development and nature of pseudocysts and cysts of Toxoplasma gondii. Transactions of the Royal Society for Tropical Medicine \& Hygiene; 52:396-407.

Lin M-H.; Chen T-C.; Kuo T-t; Tseng, C-C. and Tseng, C-P. (2000). Real-Time PCR for quantitative detection of Toxoplasma gondii. J. Clin. Microbiol., 38(11): 4121-4125

Pignanelli, S.(2011). Laboratory diagnosis of Toxoplasma gondii infection with direct and indirect diagnostic techniques.Indian. J. Pathol.Micro. ,54:786-9

Montoya, J. G. and Remington, J. S.(2008). Management of Toxoplasma gondii infection during pregnancy.J. Clin. Infect.Diseases., 47(4):554-566.

Remington, J.S.; McLeod, R.; Thulliez, P. and Desmonts, G. (2001). Toxoplasmosis,. In Remington JS, Klein J (ed), Infectious diseases of the fetus and newborn infant, 5th ed. WB Saunders, Philadelphia, PA. p 205-346.

Singh S.( 2003 ).Mother-to-child transmission and diagnosis of Toxoplasma gondii infection during pregnancy. Indian J. of Med. Microbiol.; 21(2): 6976.

Talabani, H.;Asseraf, M.;Year, H.; Delair, E.; Ancelle, T. Thulliez, P. ;Brezin, A.P. and Dupouy-Camet, J.(2009). Contributions of immune- blotting, realtime PCR, and the Goldmann-Witmercoefficient to diagnosis of atypical toxoplasmaretinochoroiditis. J Clin.Microbialogy. 47, 7:2131-2135.

Tenter, A.M., Heckeroth, A.R., Weiss, L.M.( 2000). Toxoplasma gondii: from animals to humans. Int. J. Parasitol. 30: 1217-1258 .
Tlamçan,Z.; Lemkhenete,Z and Lmimouni,BD.(2013). Toxoplasmosis :The value of molecular methods in diagnosis compared to conventional methods. JMID 3(2)93-99

Wallon, M.; Franck, J.; Thulliez, P.; Huissoud, C.; Peyron, F.; Garcia-Meric, P. and Kieffer, F.(2010). Accuracy of real-time polymerase chain reaction for Toxoplasma gondii in amniotic fluid. Obstet Gynecol.,115(4):727-33. 